\title{
Fungal Diseases of Large Cardamom (Amomum subulatum Roxb.) and its Integrated Management
}

\author{
Saroj Belbase*, Jiwan Paudel, Rivesh Bhusal, Sakar Gautam, \\ Aashma Aryal and Shrvan Kumar
}

Rajiv Gandhi South Campus, I. Ag. Sc., Banaras Hindu University, Barkachha, (Mirzapur)-231001, India

*Corresponding author

\section{Keywords \\ Leaf blight, Nursery disease, Capsule rot, Integrated disease management}

Article Info

Accepted:

26 February 2018

Available Online:

10 March 2018

\section{A B S T R A C T}

Large or Black cardamom (Amomum subulatum Roxb.) is commercially cultivated in Nepal and India. As many as 25 diseases have been reported till date. Based on severity, spread and extent of damage, these are grouped as major and minor disease occurring in main plantation and in nursery. The plant is prone to several diseases among which fungal and viral diseases cause significant loss to yield. The fungal diseases are prevalent from the nursery to plantation field. Among them four major diseases in plantations and two major diseases in nursery seriously affect plant and cause considerable crop damage. Disease can alone cause upto 50\% crop loss if not managed properly. The major fungal nursery disease are Nursery Leaf Spot (Phyllostictaelettariae), Nursery Leaf Rot (Fusarium spp. and Alternaria spp.) and Damping off or Seedling rot (Pythium vexans) while the plantation disease includes Azhukal or Capsule Rot (Phytophthora nicotianael Phytophthora meadii) and Rhizome Rot (Rhizoctonia solani) and minor fungal diseases are Leaf Blotch, Stem lodging and Capsule tip rot. Among them Nursery leaf spot, Capsule rot and Leaf blight has caused much damage. Sikkim suffers a lot from the disease of Leaf blight. Management of nursery disease is a challenging problem. These diseases spread rapidly causing the nursery destruction. Since the fungal disease are mainly associated with environmental condition, integrated disease management plays a significant role which in combination forms cultural, chemical and biological control measures.

\section{Introduction}

Black Cardamom is a species of high market value which is significantly used as a flavoring agent in various food items in the world mainly China, India, Nepal and so on. The capsule i.e. seed is used from economic point of view. It's also used in infection of teeth and gums, as a medicine of stomach disorder and malaria and also used during the antidote manufacture of snake venom or scorpion venom.

The hierarchy of large cardamom is Plantae $>$ Angiosperm $>$ Monocots $>$ Commelinds $>$ Zingiberales $>$ Zingiberaceae $>$ Ammoтит $>$ sublatum/ costatum. In world, Gautemala is the largest cardamom producing country followed by Nepal, India, Bhutan and rare parts of Papau New Guinea and Srilanka. The 
sub Himalayan region of Northeast India and Northern Eastern Nepal is considered as its native place. In Nepal it is the high value cash crop and main source of income for the farmers of Eastern Himalayan Region and also for the farmers of Sikkim, Darjeeling and Southern Bhutan. In Nepal farmers of 37 districts are engaged in its farming with 6440 tonnes of production along with area 15700 ha. Taplejung is the largest producer followed by the district Panchthar, Illam, Sankhuwasabha and so on in the year 2015-16 (Anonymous, 2015-16). In India, it is mainly grown in the sub-Himalayan tracts of Sikkim, Arunachal Pradesh, Nagaland, Darjeeling District of West Bengal and some parts of Uttarakhand. The total area under large cardamom during 2015- 16 was 26,387 ha with an estimated production of 5,300 tonnes (Anonymous, 2016). Most varieties are susceptible to diseases which are transmitted by seed and suckers. Eco friendly measures aim to reduce the harmful chemical and integrated disease management aims to sustainable use of resources for disease management. The chemicals are only used above economic threshold level.

\section{Nursery leaf spot (Phyllosticta elettariae Chowd.)}

\section{Classification}

Eukarya $>$ Fungi $>$ Ascomycota $>$ Dothideomycet es $>$ Botryosphaeriales $>$ Botryosphaeriaceae $>$

Phyllosticta elettariae

Leaf Spot Disease is a serious problem in primary nurseries causing the heavy loss of nursery seedling. Subbarao (1939) reported the disease and subsequently, Mayne (1942) indentified that the Phyllostica is the causal organism of the disease. The pathogen was isolated and detail study was done by Chowdhary and identified it as Phyllosticta elettariae Chowdhary (Chowdhary, 1948).

\section{Symptoms}

The disease is a destructive disease in primary nurseries. It appears mostly during Feb-April with the receipt of summer shower. The disease manifest as a small round or oval spots which are dull white in color. These spot later become necrotic and in the advance stages, central portion of the spot withers off leading to the formation of shot hole. The primary symptoms are yellowish to reddish brown rectangular patches on the lamina which are almost parallel to side veins (Plate- 1). In severe cases rotting of leaf is also occurred. Younger seedlings are more susceptible and susceptibility gradually decline with age.

\section{Pre-disposing factors}

The primary source of inoculum is pycinidia and the secondary source of inoculum is ascospore. High intensity of disease is noticed in open nurseries exposed to direct sunlight. High humidity and persistent dew are favorable conditions for its multiplication. It mostly appears after the receipt of summer rain. The young and tender leaves are highly susceptible than the older ones. They can survive on the plant debris for about 12 months (Naidu, 1981).

Azhukal or capsule rot (Phytophthora nicotianae var. nicotianae/ $P$. meadii)

\section{Classification}

Eukarya $>$ Straminopila $>$ Oomycota $>$ Oomycete s $>$ Pythiales $>$ Pythiaceae $>$ Phytophthora

$>$ nicotianae $>$ nicotianael meadii

Azhukal is a serious problem and a major constraint in the successful cultivation of cardamom. However, during heavy and continuous rainfall, a crop loss of $40 \%$ was estimated (Ankegowda, 2015). 'Azhukal' disease was first reported by Menon et al., 
(1972) from Idukki district of Kerala and identified Phytophthora as pathogen. While Thankamma and Pillai identified it as $P$. nicotianae var. nicotianae. Recent studies revealed that $P$. meadii of A2 mating type is a pathogenic fungus responsible for Azhukal disease (McRae, 1934).

\section{Symptoms}

The disease appears water soaked lesions on tender leaves and capsules, which later form dead areas surrounded by yellow halo. As a result, the leaves rot and shred along the veins. In the advanced stages, the affected leaves break at the base of the petiole and remain hanging. On the immature capsules, the symptoms develop as water soaked discolored areas, which later turn brownish. Upon decay, such capsules emit a foul smell and subsequently drop off (Plate- 1). The symptoms of rotting appear simultaneously on capsule and tender leaves or first on capsule followed by a foliage. Mature capsules when infected, become shriveled upon drying. Plants of all ages are susceptible to the disease (Joseph, et al., 1991).

\section{Pre-disposing factors}

This disease of cardamom is directly related to soil moisture, atmospheric humidity and number of propagules in the soil, rainfall, and number of rainy days during the period coupled with low soil and ambient temperature (Nair, 1979; Nair and Menon, 1982). Menon et al., (1972) noticed a high incidence of the disease during months of heavy and continuous rainfall, while Nair \& Menon (1982) observed that during July August with heavy rainfall and high relative humidity, the soil population levels of Phytophthora was at its peak with a high incidence of 'azhukal'. Phytophthora population in the soil and the incidence of the disease is high in gardens having high soil $\mathrm{pH}$.
With reduction in $\mathrm{pH}$ of the soil, the number of propagules is reduced. $\mathrm{pH}$ between 6 and 7 has been found favourable for the survival of the pathogen which results in increased infection (Nair, 1979; Nair and Menon, 1982). Thick shade and close spacing together with favorable climatic conditions predispose the plants to infection. Phytophthora survives in soil in the form of hyphae and sporangia for 4 to 6 weeks while as chlamydospores, it can survive as long as 48 weeks in moist soils. The pathogen is also capable of surviving in the infected rhizomes for a considerable long time and may act as a primary source of inoculum for initial infection and spread of the pathogen (Nair and Menon, 1982).

\section{Rhizome Rot (Pythiumvexans de Bary/ Rhizoctonia solani Kuhn)}

\section{Classification}

Eukarya $>$ Chromista $>$ Oomycota $>$ Oomycetes $>$ Pythiales $>$ Pythiaceae $>$ Pythiumvexans

Cardamom clumps have often been found to suffer from a disease which results in gradual decline in vigor of the plants. A number of fungi appear to be involved in the rhizomes and root-rot of cardamom.

From the rhizomes showing root diseases, Thomas (1939) also isolated $P$. vexans, from the diseased rhizomes which often became softened and underwent rotting. Ramakrishnan (1949) reported that Pythium vexans could be isolated from the diseased rhizomes of plants growing at elevations of 1000-1500 m only.

\section{Symptoms}

The disease is often confused with mosaic but infected plants can be easily distinguished by paleness and yellowishness and eventual death of young foliage instead of any mosaic pattern. 


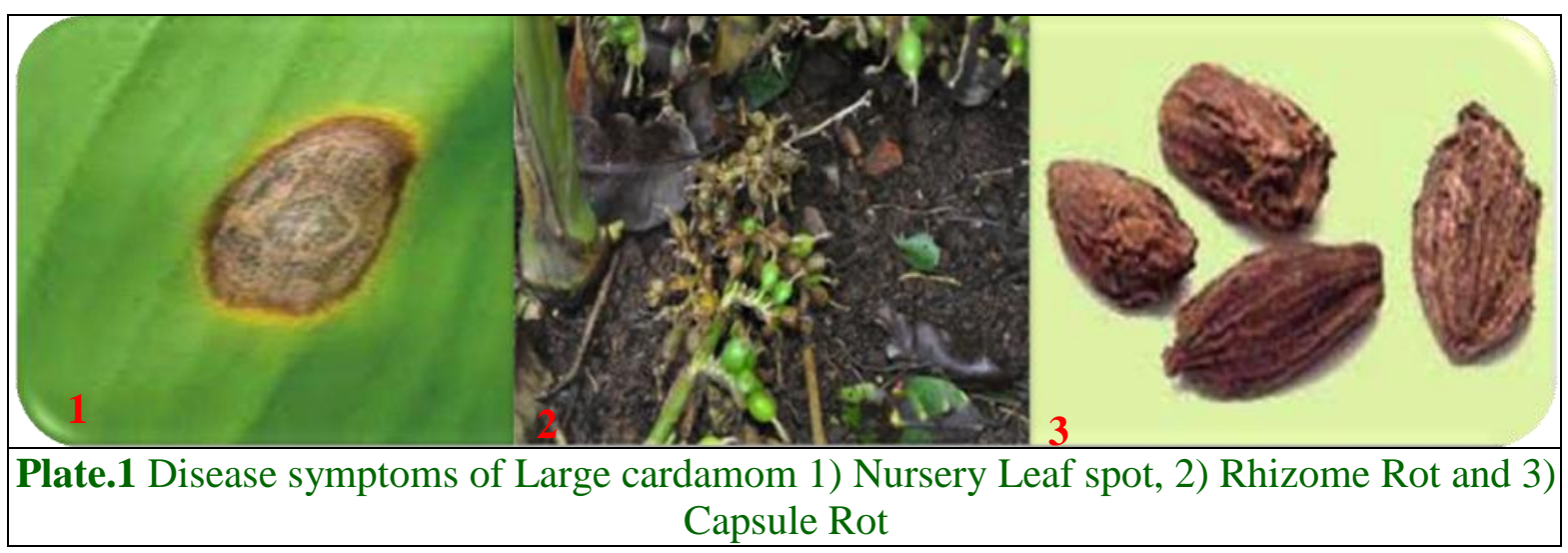

Older leaves usually die prematurely and new shoots are weak and unhealthy. Later, decay and rotting of the rhizomes at stem bases are noticed. Shoots become very brittle at the region, collapse and can be pulled out easily. The diseased clums can often be spotted from a distance by the presence of the fallen shoots (Plate- 1). Rhizomes are often found to be rotten and covered with fungal mycelium. Affected plants may contain rhizome borer Prodioctes haematicus. In every case of attack, there is extensive decay of the root system. This disease has not yet been found to be serious in well-managed plantations, though it may be occasionally severe in isolated gardens (Mayne, 1942).

\section{Pre-disposing factors}

The disease is soil-borne one. Infected rhizomes also plays positive role in the spread of the disease. The role of environmental factors and soil conditions on the incidence of this disease has not been investigated. Mayne (1942) stated that this trouble may be owing to insufficient drainage in a few cases, but in general the incidence of the disease is not influenced by environmental conditions. Ananda Rau and Venkataramani (1949) observed this disease in clumps growing in moist soil near the streams. The disease is usually serious in land previously infested with thicket Ochlandra travancorica. The spread of disease takes place by oospore which serves as a secondary source of inoculum.

\section{Disease management}

\section{By cultural methods}

Raise nursery in fertile soil.

Early sowing of suckers in August-September will ensure mature seedlings which are less prone to diseases during south west monsoon.

Collect and destroy disease infected and insect damaged plant parts

Provide irrigation at critical stages of the crop

Avoid water logging

Regulate shade in thickly shaded areas.

Avoid water stress during flowering stage

Remove and destroy collateral/alternate hosts such as castor, ginger, turmeric in the immediate vicinity.

Encouragement of golden backed woodpecker and crow-pheasant in the plantation and installation of bird perches to attract birds of economic importance in biological control.

Maintain optimum plant density. 
Gaps fill with healthy disease free materials.

Mulching the plant basins with green leaves and other organic materials during summer months conserves and maintains the population of native beneficial microflora.

\section{By bio-pesticides methods}

Deep suckers in leaf extracts of neem or Madar or Eucalyptus@ @25\% concentration for 1 hour and then transplanting.

Sun-derma (Trichoderma viride), Eco-fit (Trichoderma spp.), Glio-Guard (Trichodermavirens) @10g per kg FYM mix and covered with wet gunny beg for 10 days after that broadcasting in the field.

Deep suckers in Trichoderma or Pseudomonas florescence or Bacillus subtilis @ 5g/ L water for 1 hour and then transplanting.

Trichoderma harzianum mass multiplied on suitable carrier media may be applied to plant basins@1 kg during May and SeptemberOctober (Suseela et al., 1992).

To apply spray of Jatropha or neem oil @ $2 \mathrm{ml} / \mathrm{L}$ of water.

Biological control of $P$. meadii infections using antagonistic fungi such as Trichoderma spp. and Laetisaria sp. has been found effective in managing 'azhukal' disease (Suseela et al., 1992).

\section{By chemical methods}

Prophylactic spraying with fungicides such as Bordeaux mixture (1\%) or copper oxychloride $(1 \%)$ or Mancozeb $(0.2 \%)$ may be given at fortnightly intervals. Depending on the severity of the disease, two to three rounds of spraying may be given.
Spray/drench the soil after germination of seedlings with copper oxy chloride@ 1 g/Lwater

Suckers treated with demason or apron 35SD or metalexil 25WP@ 2g per liter water or benomyl 25WP or bevistin 50WP or plantvex 75WP@2.5g per liter water and then showed.

Apply sprayed of dithan Z-78 or Lonacol or Difolatan or Indofil M-45 or Mencozeb @ $2.5 \mathrm{~g}$ per liter water at $7-10$ days interval.

\section{References}

Ananda Rau, S. and Venkalaramani, K.S. (1949). Mycological report of the Botanist. Unit. Plant. Ass. S. India. 1948-49: 15-21.

Ankegowda, S.J., Biju, C.N., Jayashree, E., Prasath, D., Praveena, R., Kumar, S.C.M. and Srinivasan, V., (2015). Cardamom - Extension Pamphlet November-2015, Agricultural Technology Information Centre ICARIndian Institute of Spices Research Kozhikode - 673 012, Kerala. 1-26 pp.

Anonymous, (2015-16). Statistical information on Nepalese Agriculture Government of Nepal Ministry of Agricultural Development Monitoring, Evaluation and Statistics Division Agri Statistics Section Singha Durbar, Kathmandu Nepal, pp. 1-219.

Anonymous, (2016). Annual Report, (201516)-Spices Board, Ministry of Commerce and Industry, Government of India, Sugandha Bhavan, P B No: 2277, Cochin - 682 025. pp. 162.

Chowdhary, S. (1948). Notes on fungi from Assam III. Lloydia 21: 152-156.

Joseph, T., Suseela Bhai, R.and Naidu, R., (1991). Capsule rot disease of cardamom and its control. J. Plantn. Crops (Suppl.) 18: 264-268. 
Mayne, W. W., (1942). Report on cardamom cultivation in S. India. Misc. Bull. No: 50. Imp. Counc. Agric. Res., India.

McRae, W. 1934. Foot rot diseases of Piper belle in Bengal. Indian J. agric. Sci. 4: 585-617.

Menon, M. R., Sajoo, B. V., Ramakrishnan, C. K. and Remadevi, L., (1972). A new Phytophthora disease of cardamom. Curro. Sci. 41: 231.

Naidu, R., (1981). Morphology, parasitism and epidemiology of Phyllosticta elettariae Chowdhury causing leaf spot disease of cardamom. J. Plant. Crops 9: 23-27.

Nair, R. R., (1979). Investigations of fungal diseases of cardamom. Ph.D Thesis, Kerala Agricultural University, Vellanikkara, Trichur.
Nair, R. R. and Menon, M. R. (1982). Azhukal diseases of cardamom In: Nambiar K K (Ed.) Proc. Workshop on Phytophthora Diseases of Tropical Cultivated Plants, 19-23 September 1980 (pp. 24-33). Central Plantation Crops Research Institute, Kasaragod, India.

Ramakrishnan, T.S. (1949). The occurrence of Pythium vexons de Bary in South India. Indian Phytopath. 2: 27-30.

Subbarao. M.K., (1939). Report of Mycologist 1937-39. 1937-38: 28-37; 1938-39: 2842.

Suseela Bhai R, Joseph T and Naidu R 1992 Evaluation of promising selections of cardamom against azhukal disease. $J$. Plantn. Crops 20 (Suppl.): 90-91.

Thomas, K.M. (1939). Rep. Subord. Offices Dep. Agric. Madras, 1938-39, p. 130.

\section{How to cite this article:}

Saroj Belbase, Jiwan Paudel, Rivesh Bhusal, Sakar Gautam, Aashma Aryal and Shrvan Kumar. 2018. Fungal Diseases of Large Cardamom (Amomum subulatum Roxb.) and Its Integrated Management. Int.J.Curr.Microbiol.App.Sci. 7(03): 3316-3321. doi: https://doi.org/10.20546/ijcmas.2018.703.382 